\title{
Ateleia glazioveana and Ocimum basilicum: plants with potential larvicidal and repellent against Aedes aegypti (Diptera, Culicidae)
}

\author{
Ateleia glazioveana e Ocimum basilicum: plantas com potencial larvicida e repelente frente ao Aedes \\ aegypti (Diptera, Culicidae)
}

Ateleia glazioveana y Ocimum basilicum: plantas con potencial larvicida y repelente contra Aedes aegypti (Diptera, Culicidae)

Received: 11/00/2021 | Reviewed: 12/00/2021 |Accept: 12/24/2021| Published: 12/27/2021

Kelly Alievi

ORCID: https://orcid.org/0000-0002-5315-1350

Universidade Comunitária da Região de Chapecó, Brasil

E-mail: kellyalievi6@gmail.com

Giovana Tamara Capoani

ORCID: https://orcid.org/0000-0002-3752-062X

Universidade Comunitária da Região de Chapecó, Brasil

E-mail: capoani.giovana@unochapeco.edu.br

Maike Buzatto

ORCID: https://orcid.org/0000-0001-5416-8667

Universidade Comunitária da Região de Chapecó, Brasil

E-mail: maikebuzatto@gmail.com

Daniela Miorando

ORCID: https://orcid.org/0000-0003-2618-8120

Universidade Comunitária da Região de Chapecó, Brasil E-mail: daniela.m@unochapeco.edu.br

Patrícia Zanotelli Serpa

ORCID: https://orcid.org/0000-0002-4173-1833

Universidade Comunitária da Região de Chapecó, Brasil

E-mail: patricia.zanotelli@unochapeco.edu.br

Odinei Fogolari

ORCID: https://orcid.org/0000-0003-3055-2490

Universidade Federal da Fronteira Sul, Brasil

E-mail: odinei.fogolari@uffs.edu.br

Zuleide Maria Ignácio

ORCID: https://orcid.org/0000-0002-1417-1308

Universidade Federal da Fronteira Sul, Brasil

E-mail: zuleideignacio@gmail.com

Daniel Albeny Simões

ORCID: https://orcid.org/0000-0002-8001-030X Universidade Comunitária da Região de Chapecó, Brasil

E-mail: danielalbeny@gmail.com

Maria Assunta Busato

ORCID: https://orcid.org/0000-0003-0043-7037 Universidade Comunitária da Região de Chapecó, Brasil

E-mail: assunta@unochapeco.edu.br

Junir Antônio Lutinski

ORCID: https://orcid.org/0000-0003-0149-5415 Universidade Comunitária da Região de Chapecó, Brasil

E-mail: junir@unochapeco.edu.br

Walter Antônio Roman Junior

ORCID: https://orcid.org/0000-0001-8363-8795 Universidade Comunitária da Região de Chapecó, Brasil

E-mail: romanwa@unochapeco.edu.br

\begin{abstract}
The Aedes aegypti is the main vector of the transmission of diseases such as dengue, yellow fever, Chikungunya, and Zika. The agents used for the control of mosquito involve the use of synthetic compounds, which may cause toxicity and contamination environmental. Aiming to test the effectiveness of natural products, the aim of this study was to evaluate the larvicidal and repellent activity of extracts of Ateleia glazioveana Baill. (timbó) and essential oil of Ocimum basilicum L. (manjericão), against A. aegypti. The activities of hydroalcoholic (HEA) and dichloromethane
\end{abstract}


(DEA) extracts from A. glazioveana against $A$. aegypti larvae were assessed after exposure for 24,48 , and $72 \mathrm{~h}$, using water and Bacillus thuringiensis israelensis as negative and positive controls, respectively. For repellent evaluation, we investigated the sting attempts of $A$. aegypti in response to the application of HEA- and DEA-based body creams (5\%), as well as an alcoholic spray based on the essential oil from O. basilicum. The repellency of these preparations was compared with negative (vehicle) and positive (DEET) controls. Although HEA showed no apparent larvicidal activity, DEA at concentrations of 150 to $500 \mu \mathrm{g} / \mathrm{ml}$ showed high larvicidal potential after $24 \mathrm{~h}$, compared to the negative control group ( $<<0.001)$. Moreover, the DEA-based cream and the alcoholic spray of $O$. basilicum based essential oil showed higher repellency compared with the vehicle (84.5\% and $70.5 \%$, respectively). Accordingly, it is possible to infer that extracts and preparations of A. glazioveana and O. basilicum exhibit larvicidal and repellent activity against $A$. aegypti.

Keywords: Dengue; Natural product; Repellency.

\section{Resumo}

O Aedes aegypti é o principal vetor de transmissão de doenças como dengue, febre amarela, Chikungunya e Zika. Os agentes utilizados para o controle do mosquito envolvem o uso de compostos sintéticos contudo, estes podem causar toxicidade e contaminação ambiental. Visando testar a efetividade de produtos naturais, o objetivo deste estudo foi avaliar a atividade larvicida e repelente dos extratos de Ateleia glazioveana Baill. (timbó) e óleo essencial de Ocimum basilicum L. (manjericão), frente ao A. aegypti. As atividades dos extratos hidroalcoólico (HEA) e diclorometano (DEA) de A. glazioveana foram avaliadas após exposição por 24, 48 e 72 h, utilizando água e Bacillus thuringiensis israelensis como controle negativo e positivo, respectivamente. Para avaliação repelente, foi investigado as tentativas de picadas de A. aegypti em resposta à aplicação de cremes corporais à base de HEA e DEA (5\%), além de um spray alcoólico à base de óleo essencial de $O$. basilicum. A repelência dessas preparações foi comparada com os controles negativo (veículo) e positivo (DEET). Embora HEA não tenha demonstrado atividade larvicida aparente, DEA nas concentrações de 150 a $500 \mu \mathrm{g} / \mathrm{ml}$ apresentou elevado potencial larvicida após $24 \mathrm{~h}$, em comparação com o grupo de controle negativo ( $<0,001)$. Além disso, o creme à base de DEA e o spray alcoólico de óleo essencial à base de $O$. basilicum apresentaram maior repelência em relação ao veículo (84,5\% e 70,5\%, respectivamente). Assim, é possível inferir que extratos e preparações de $A$. glazioveana e $O$. basilicum exibem atividade larvicida e repelente frente $A$. aegypti.

Palavras-chave: Dengue; Produto natural; Repelência.

\section{Resumen}

Aedes aegypti es el principal vector de transmisión de enfermedades como el dengue, la fiebre amarilla, el chikungunya y el zika. Los agentes utilizados para el control de mosquitos involucran el uso de compuestos sintéticos, sin embargo, estos pueden causar toxicidad y contaminación ambiental. Con el objetivo de probar la eficacia de los productos naturales, el objetivo de este estudio fue evaluar la actividad larvicida y repelente de los extractos de Ateleia glazioveana Baill. (timbó) y aceite esencial de Ocimum basilicum L. (mangericão), contra A. aegypti. Se evaluaron las actividades de los extractos hidroalcohólicos (HEA) y diclorometano (DEA) de A. glazioveana después de la exposición durante 24, 48 y 72 h, utilizando agua y Bacillus thuringiensis israelensis como controles negativos y positivos, respectivamente. Para la evaluación del repelente, se investigaron los intentos de picar A. aegypti en respuesta a la aplicación de cremas corporales a base de HEA y DEA (5\%) y un spray alcohólico a base de aceite esencial de $O$. basilicum. La repelencia de estas preparaciones se comparó con controles negativos (vehículo) y positivos (DEET). Aunque HEA no mostró actividad larvicida aparente, DEA en concentraciones de $150 \mathrm{a} 500 \mu \mathrm{g} / \mathrm{ml}$ mostró un alto potencial larvicida después de $24 \mathrm{~h}$, en comparación con el grupo de control negativo (p < 0,001). Además, la crema a base de DEA y el spray de aceite esencial alcohólico a base de $O$. basilicum mostraron mayor repelencia en relación al vehículo $(84,5 \%$ y 70,5\%, respectivamente). Así, es posible inferir que los extractos y preparaciones de $A$. glazioveana y $O$. basilicum exhiben actividad larvicida y repelente contra $A$. aegypti.

Palabras clave: Dengue; Producto natural; Repelencia.

\section{Introduction}

As a consequence of environmental modification attributable to detrimental anthropic activities, mainly driven by economic factors, in parallel with climate change, many vector insects such as mosquitoes have become synanthropic, preferentially mediating the transmission of pathogens to humans (Lima-Camara, 2016). Arthropod-borne viruses (arboviruses) pose an important problem of public health worldwide, infecting millions of individuals and causing a large social and economic (Agarwal et al., 2017).

In addition, diverse urban practices and vehicular activity have become increasingly prominent factors contributing to the spread for example, of mosquito Aedes aegypti (Linnaeus, 1762) (Diptera: Culicidae) (Xavier et al., 2013). The females of 
this species are the principal vectors of diseases as dengue, yellow fever, and Chikungunya, transmitting these viruses via hematophagy. As efforts to minimize the extent of such transmission, numerous prophylactic measures have routinely been adopted, including the elimination of potential breeding sites, the use of insecticides to control adult mosquito (adulticides) and larva (larvicides) populations, and the use of repellents to protect individuals against biting females (Rosa, 2016; Zara et al., 2016).

A strategy for arbovirus control, such as dengue, is the use of synthetic chemicals to adult vectors using space spraying. However, the majority of insecticides are of the pyrethroid chemical class, creating challenges to preventing selection pressure on susceptible mosquito populations, as well as the control of resistant vectors (Corbel et al., 2016). For combat specifically of $A$. aegypti, larval control has long been proposed and implemented as a primary strategy, including applications of chemical and microbial larvicides, insect growth regulators, and bacterial toxins (Poopathi \& Abidha, 2010). However, the continued use of synthetic insecticides is relation causes environmental damage and contributes to the emergence of resistant mosquitoes populations (Rosa, 2016; Guarda et al., 2016). In addition, most of the repellents (synthetic chemicals) commonly applied, can have adverse effects, promoting alterations in the central nervous system and allergic reactions (Diaz, 2016). In order to achieve more effective and safer results, pharmacological studies with substances extracted from plants have been intensified (Newman \& Cragg, 2016). Medicinal plants have been a valuable source of successful therapeutic agents, the production of chemically diversified secondary metabolites are optimized to exert biological functions (Atanasov et al., 2015).

Ateleia glazioveana Baill. (Fabaceae), commonly known as maria-preta, cinamomo-bravo, or timbó, is a species of a deciduous tree native to Brazil that can reach heights of 8-20 m and is found most commonly in the states of Rio Grande do Sul and Santa Catarina. Its leaves are palatable and often serve as cattle feed during periods of drought (Long, 1995). However, in rural areas, it has been established that if the foliage is consumed in large quantities by cattle $(40 \mathrm{~g} / \mathrm{kg})$, it can cause toxic symptoms (Gava \& Barros, 2001). Charcoal from the plant (prepared as tea) is popularly used for the treatment of appendicitis as well as for rubbing on children's joints and legs for strengthening (Franco \& Fontana, 1997). Nevertheless, A. glazioveana is also considered to possess insecticidal potential (Ortega \& Schenkell, 1986) due to the presence of rotenone in the extracts (Migliorini et al., 2010).

Although native to Asia and Africa, plant Ocimum basilicum L. (Lamiaceae) is globally found and is widely used as a culinary herb. In Brazil, the plant is known as mangericão or basilicão, whose leaves are regularly used in the treatment of fever, cold, and bronchitis. The chemical analysis of the plant has revealed the presence of volatile constituents such as linalool, eugenol, cineole, and pyrene (Lorenzi \& Matos, 2002), which are biologically active and have been demonstrated potential insecticidal effects (Deshpande \& Tipnis, 1997).

Considering the widespread usage of these plants and the findings insecticide of previous studies, this study aim to evaluate the larvicidal activity of the extracts of A. glazioveana as well as the repellent activity of body creams prepared from these plant extracts. In addition, the repellency of an alcoholic spray based on the essential oil obtained from $O$. basilicum was investigated.

\section{Methodology}

This study is classified as analytical, experimental in nature, with a quantitative approach and developed in the laboratory. In this type of investigation, the researcher selects the variables that will be studied and actively participates in the conduct and/or observation of the phenomenon, process or fact evaluated, that is, he acts on the cause, modifying it, and evaluates changes in the outcome (Pereira et al., 2018: Scorsolini-Comin, 2021). 


\section{Plant material and production of extracts}

The leaves of A. glazioveana and O. basilicum were collected in Chapecó (SC), Brazil (2701'55.14"'S and $52^{\circ} 47^{\prime} 29.42^{\prime \prime}$, respectively), in September 2018. The plants were identified by Prof. Adriano Dias de Oliveira, the curator of the Herbarium of the Community University of the Region of Chapecó, wherein voucher specimens have been deposited (\#3682 and 4006, respectively). This research is registered (protocol number: A25B0E1) in the National System for Governance of Genetic Heritage and Associated Traditional Knowledge (SisGen).

In order to study the larvicidal and repellent effects of A. glazioveana, extracts of reduced (dichloromethane) and high polarity (hydroalcoholic) were produced with the leaves of the plant. Hydroalcoholic (HEA) and dichloromethane (DEA) extracts were prepared by maceration (5 days) using dry-milled leaves (50 g) and ethanol $70 \%$ (2000 ml). The extracts thus obtained were filtered in the Büchner funnel, concentrated by evaporation under reduced pressure $\left(40^{\circ} \mathrm{C}\right)$, and lyophilized (Brasil, 2019).

The extraction of essential oil from the leaves of $O$. basilicum was done in a Clevenger apparatus, coupled to a bottom flask $(500 \mathrm{ml})$. It was added dry-milled leaves of the plant $(50 \mathrm{~g})$ and water into the flask $(500 \mathrm{ml})$. The extraction time was fixed at 4 hours. Then, the essential oil was dried using $\mathrm{Na}_{2} \mathrm{SO}_{4}$ to remove the water (Brasil, 2019).

\section{Chemical analysis}

The quantification of the flavonoids in the extracts from A. glazioveana was performed according to Woisky and Salatino (1998), with minor modifications. Briefly, $1 \mathrm{ml}$ aliquots of the extracts $(1000 \mu \mathrm{g})$ were added to $1 \mathrm{ml} \mathrm{AlCl}_{3}(2 \%$ in $\mathrm{MeOH})$. After $60 \mathrm{~min}$, spectrophotometry was performed $(\mathrm{n}=3)$ at $365 \mathrm{~nm}$, and concentrations of samples were determined on the basis of a calibration curve prepared from a quercetin standard (10-30 $\mu \mathrm{g} / \mathrm{ml}$ ) (anhydrous Sigma-Aldrich® USA, lot: 020M1566), and expressed in terms of milligrams per gram of extract.

The chemical analysis of the essential oil from $O$. basilicum was performed through gas chromatography coupled with mass spectrometry (GC/MS) conducted on a Shimadzu QP2010 S system (Tokyo, Japan). Aliquots (10 mg) of the oil were diluted in dichloromethane $(2 \mathrm{ml})$ and injected using a 1:40 ratio in MeOH. Fractionation was carried out using a DB-1 analytical column $(30 \mathrm{~m} ; 0.25 \mathrm{~mm})$, with dimethylpolysiloxane being used for separation and helium as a carrier gas at a flow rate of $0.80 \mathrm{ml} / \mathrm{min}$; the injector (split mode, $1: 40$ split ratio) was maintained at $300^{\circ} \mathrm{C}$. The initial temperature of the column was adjusted to $80^{\circ} \mathrm{C}$, at which it was maintained for $1 \mathrm{~min}$; the temperature was then ramped at $5^{\circ} \mathrm{C}$ min to $190^{\circ} \mathrm{C}$, then at $20^{\circ} \mathrm{C}$ min to $300^{\circ} \mathrm{C}$, and finally at $15^{\circ} \mathrm{C}$ min to $310^{\circ} \mathrm{C}$, where it was held for $10 \mathrm{~min}$. The MS detector was operated in the sweep mode $(m / z=29-500 \mathrm{Da})$ at $70 \mathrm{eV}$ and positive electrical impact ionization methods were employed (Tyagi \& Malik, 2012). The constituents were identified by comparison of the mass spectra of the samples with those of the standard obtained from a data system library (NIST version 8.0), and the corresponding values were compared with those reported in the literature (Adams, 2007).

\section{Collection of A. aegypti eggs and maintenance of larvae, pupae, and adults}

For the purposes of larvicidal evaluation, ovitrap-type traps were used to collect the eggs of A. aegypti in Chapecó (SC, Brazil) in December 2018. The eggs contained in the vane were placed in six trays, each of which contained 2 liters of distilled water. After hatching, the larvae were maintained under controlled temperature $\left(29 \pm 3^{\circ} \mathrm{C}\right)$ conditions, with a photoperiod of $12 \mathrm{~h}$, and fed with fish feed until reaching the $2^{\text {nd }}$ and $3^{\text {rd }}$ stages of development (approximately $72 \mathrm{~h}$ ) (Guarda et al., 2016). 
For the repellency assay, pupae were collected from the culture trays and transferred to plastic containers $(20 \times 20 \mathrm{~cm})$ containing $500 \mathrm{ml}$ of water, which were maintained in a $90 \times 90 \times 90 \mathrm{~cm}$ cage for mosquito adults under controlled temperature $\left(29 \pm 3^{\circ} \mathrm{C}\right)$ conditions, with a photoperiod of $12 \mathrm{~h}$. The adults were provisioned with a $10 \%$ sugar solution for a period of 3 days prior to exposing rats to female mosquitoes for blood feeding.

\section{Larvicidal bioassay}

For the larvicidal tests, A. aegypti larvae (25) at the $2^{\text {nd }}$ and $3^{\text {rd }}$ stages of development were exposed to HEA and DEA extracts $(50,150,250$, and $500 \mu \mathrm{g} / \mathrm{ml} ; \mathrm{n}=5)$ diluted in water and Polysorbate 80 (Tween 80, 0.5\%) (25 ml) and provisioned with commercial fish feed. The negative control (NC) was performed with Chlorine-free water + Tween $80(0.5 \%)$ and the positive control (PC) used was the Bacillus thuringiensis (BTI: $0.04 \mathrm{~g} / 1+$ Tween 80: 0.5\%) (CP). Larval mortality was recorded after exposure for 24, 48, and 72 h (Coelho et al., 2009; Guarda et al., 2016).

\section{Repellent activity}

This phase of the study was approved by the Ethics Committee of Unochapecó (3.314.981). For repellency assessment, non-ionic-based creams containing 5\% HEA or DEA as well as an alcoholic spray based on the essential oil obtained from $O$. basilicum (5\%) were prepared. For the determination of repellent activity, an acrylic box $\left(27.000 \mathrm{~cm}^{3}: 41 \times\right.$ $41 \times 16)$ with openings covered by a screen, through which the volunteer's forearm could be extended till a distance of $150 \mathrm{~mm}$, which prevented the volunteer from being bitten. Female A. aegypti $(\mathrm{n}=50)$ were introduced into the box and allowed to acclimate for $20 \mathrm{~min}$. The arms of the volunteers were washed with Extran $5 \%$ (25 ml per arm), then rinsed with water and dried. Thereafter, $25 \mathrm{ml}$ of isopropyl alcohol (50\%) was applied to each arm and allowed to dry naturally.

For evaluation, one the following preparations was applied to the forearms of the volunteers: the vehicle (the vehicle formulations used, Vhe); DEET (a preparation of commercial OFF®; positive control); body creams based on extracts of $A$. glazioveana and an alcoholic spray based on the essential oil from O. basilicum. For all tests, one of the volunteers' forearms without the application of any formulation was exposed to mosquitoes within the box as a negative control (NC). Evaluations were conducted over a 3-min period, during which the number of bite attempts $(n=3)$ was recorded. The percentage repellency (\%R) was determined using the following equation (Paula et al., 2004):

$$
\% \mathrm{R}=[(\mathrm{TV}-\mathrm{TA}) \times 100) / \mathrm{TV}]
$$

Where: TV and TA are the number of bites inflicted on the forearms of the volunteers exposed to the vehicle and the sample, respectively.

\section{Statistical analysis}

All collected data were initially analyzed using the Kruskal-Wallis test to determine normal distributions. Statistically significant differences were determined on the basis of an analysis of variance (ANOVA) followed by Bonferroni correction using GraphPad version 6.00 for Windows (GraphPad Software, La Jolla, CA, USA). The values were presented as the means \pm standard error of the means (S.E.M), with a p-value of less than $0.05(\mathrm{p}<0.05)$ taken to be indicative of a significant observation. Percentage mortality (\%) and median mortality were determined using Finney’s probit model for estimating the half maximal lethal concentration $\left(\mathrm{LC}_{50}\right)$ with $95 \%$ confidence limits. 


\section{Results and Discussion}

The search for natural products, as potential alternatives to synthetic preparations, to control A. aegypti has contributed to the development of several effective pharmaceutical formulations (Sharma et al., 1981; PAVELA et al., 2016). In this study, which is the first to evaluate the potential larvicidal and repellent activities of extracts derived from $A$. glazioveana and $O$. basilicum and their phytoterapic formulations, the observed effects were found to be attributable to the properties of the polyphenolic compounds and essential oils. In this regard, high quantities of flavonoids were detected in the HEA and DEA extracts of A. glazioveana (48.25 and $33.18 \mathrm{mg} / \mathrm{g}$ of extract, respectively), thereby indicating the presence of these molecules in the extracts of both low and high polarity. These results are according to Ortega et al. (1986) that pointed an elevated quantity of flavonoid rutin, in the hydroalcoholic extract of leaves of A. glazioveana collected in spring.

Chemical analyses of the essential oil of $O$. basilicum through GC/MS revealed the presence of 11 compounds, whose principal constituent was identified as eucalyptol, accounting for $26.84 \%$, followed by $18.4 \%$ linalool and $17.1 \%$ eugenol, respectively (Table 1). Although the presence of these compounds in the leaves of the plants has previously been described in the literature (Ortega \& Schenkel, 1987; Pandey et al., 2014) the present study is the first in which these molecules are related to the effects larvicidal and repellent.

Table 1. Chemical composition of essential oil from Ocimum basilicum.

\begin{tabular}{|c|c|c|c|c|}
\hline $\begin{array}{l}\text { Peak } \\
\text { Number }\end{array}$ & $\begin{array}{l}\text { Retention } \\
\text { time/min }\end{array}$ & Compounds & $\begin{array}{l}\text { Molecular } \\
\text { mass (Da) }\end{array}$ & Area $(\%)$ \\
\hline 1 & 7.68 & Eucalyptol & 154.25 & 26.84 \\
\hline 2 & 9.09 & Linalool & 154.25 & 18.84 \\
\hline 3 & 9.97 & $\alpha$-Bergamotene & 338.39 & 14.54 \\
\hline 4 & 10.89 & $\alpha$-terpineol & 154.25 & 4.49 \\
\hline 5 & 14.00 & Eugenol & 164.20 & 17.05 \\
\hline 6 & 14.69 & Bisabolene & 204.35 & 1.68 \\
\hline 7 & 15.20 & B-cariofilene & 204.35 & 2.73 \\
\hline 8 & 15.43 & Cis- $\alpha$-bergamotene & 204.35 & 3.06 \\
\hline 9 & 16.23 & Germacrene D & 204.35 & 4.57 \\
\hline 10 & 16.74 & Naftalene & 128.17 & 1.57 \\
\hline 11 & - & N.I* & - & 1.02 \\
\hline 11 & 18.73 & Cadinol & 222.37 & 4.04 \\
\hline
\end{tabular}

*N.I = Not identified. Source: Authors.

Aedes aegypti (Linnaeus, 1762), is the main transmitting insect of the Chikungunya viruses (CHIKV; Alphavirus genus), Dengue (DENV; Flavivirus genus), and Zika (genus Flavivirus) in humans (Rückert et al., 2017). Among the insecticides used to combat the mosquito vector, organochlorine, organophosphate, carbamates and pyrethroid insecticides stand out. However, the continued use of these chemicals has promoted the emergence of more resistant insect populations and 
caused damage to the environment (Braga \& Valle, 2007). Thus, extracts or compounds extracted from plants have been prospected and several molecules have shown proven activity against $A$. aegypti larvae (Garcez et al., 2013).

This study, the bioassays evaluating the larvicidal activity of two different extracts of A. glazioveana toward A. aegypti are shown in Figure 1. The HEA extract was found to be inactive even at the highest concentration $(500 \mu \mathrm{g} / \mathrm{ml})$ assessed. Contrastingly, DEA at all assessed concentrations (50,150,250, and $500 \mu \mathrm{g} / \mathrm{ml}$ ), particularly at 150, 250, and 500 $\mu \mathrm{g} / \mathrm{ml}$, exhibited high activity during the initial $24 \mathrm{~h}$ of exposure, accounting for percentage larval mortalities of $6.66 \%, 93.3 \%$, $94.6 \%$, and 99\%, respectively. The higher larvicidal activity of DEA than that of HEA can be attributed to the higher proportion of lipophilic constituents present in the extracts of lower polarity (rotenone, for example), which would facilitate the permeation of cellular membranes (Lee \& Houghton, 2005). To gain a better understanding of this larvicidal potential, the half maximal lethal concentration $\left(\mathrm{LC}_{50}\right)$ values for the DEA extract was calculated and an $\mathrm{LC}_{50}$ of $95.4 \mu \mathrm{g} / \mathrm{ml}$ at $24 \mathrm{~h}$ was obtained, which decreased to $79.4 \mu \mathrm{g} / \mathrm{ml}$ after $48 \mathrm{~h}$, with a similar value being calculated for the larvae exposed for $72 \mathrm{~h}$. With respect to larvicidal activity, it is generally considered that an extract with the $\mathrm{LC}_{50}$ value of $<50 \mu \mathrm{g} / \mathrm{ml}$ is very active, whereas those with values of 50-100 $\mu \mathrm{g} / \mathrm{ml}$ and $100 \mu \mathrm{g} / \mathrm{ml}$ are considered active and weak/inactive, respectively (Carneiro et al., 2021). Thus, the study confirms the larvicidal potential of the chemical constituents within the DEA extract, which include flavonoids, detected at a concentration of $48.2 \mathrm{mg} / \mathrm{g}$.

Figure 1 - Mortality of Aedes aegypty larvae (\%) compared to treatments $(n=5)$ at 24, 48 and 72 hours. PC (positive control): Bacillus thuringiensis israelensis (0.04 g/l); NC (negative control): water chlorine-free; HEA500: Hydroalcoholic extract of Ateleia glazioveana $(500 \mu \mathrm{g} / \mathrm{ml})$; DEA: Dichloromethane extract of Ateleia glazioveana $(50-500 \mu \mathrm{g} / \mathrm{ml}) . * * * \mathrm{p}<0.001$ compared to NC.

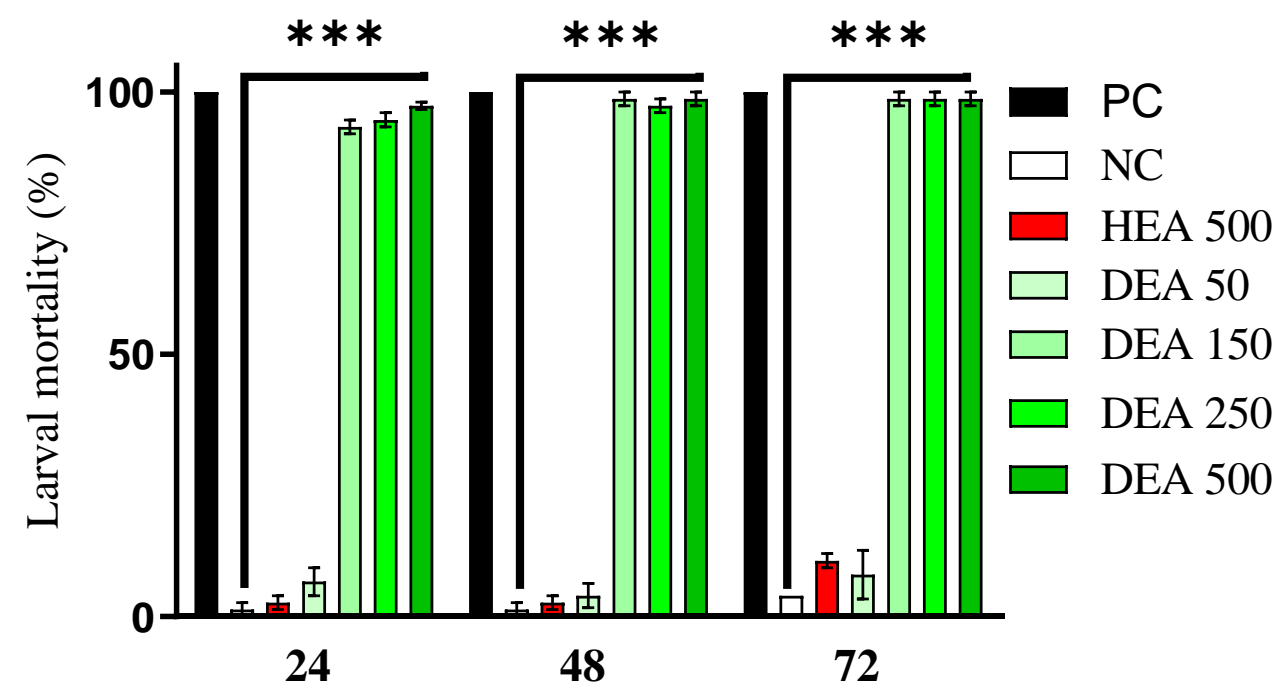

Evaluation (hours)

Source: Authors.

In fact, flavonoids, more specifically rotenones showed promising larvicidal activity in combating the mosquito vector A. aegypti, suggesting a great potential for the use of flavonoids, as well as those derived from this class of natural 
products as raw material for the production of new biopesticides (Vasconcelos et al., 2012). These compounds, along with polyphenols, have been established to have toxic effects on insects and larvae (Garcez et al., 2013; Guarda et al., 2016). The mode of action of flavonoids on mosquito larvae are not well known, but previous studies pointed that insecticidal action relating to aromatic and phenolic components such as flavonoids, commonly occurs due to acetylcholinesterase (AChE) inhibition and interference in the insect's octopaminergic system (Isman, 2006). The aforementioned compounds can also suppress ecdysteroids and therefore impact insect growth regulation (Copping \& Duke, 2007). In addition, Usta et al. (2002) demonstrated that these compounds interfered with the proper functioning of mitochondria more specifically, at the proton transferring sites. These effects exerted by flavonoids may explain, in part, the larvicidal effect of A. glazioveana extracts.

Repellents are organic compounds that occur naturally or are produced by synthesis to make surfaces unpleasant or unattractive to organisms like insects, animals, or plants (Moore \& Debboun, 2007; Idris et al., 2014). The repellent formulations typically contain substances that repels unwanted organisms as well as secondary ingredients, which aid in delivery and cosmetic appeal (Who, 2006). They are available in many forms, from cream to oils and sprays and exert an important role in preventing vector-borne diseases by reducing man-vector contact (Knowlton \& Pearce, 1993; Idris et al., 2014).

Topical repellents, either synthetic or natural, act by forming a vapor layer on the skin surface, releasing an odor to inactivate insect functions (Paumgartten \& Delgado, 2016). Although synthetic products are economically advantageous and have been widely used, natural products have the potential to provide efficient and safer repellency and are notably more environmentally friendly (Corrêa \& Salgado, 2011). In this study, the body creams based on HEA and DEA (5\%), as well as the alcoholic spray containing the essential oil of O. basilicum (5\%) showed higher repellent activity (Figure 2) than the corresponding vehicle groups $(\mathrm{p}<0.01$ and $\mathrm{p}<0.001)$.

Insects detect specific scents via odorant receptors (ORx), which form complexes with co-receptors (Oreo). The binding of an odorant to ORx promotes the opening of Oreo ion channels, thereby activating sensory neurons that detect the odor. Consequently, allosteric agonists and antagonists that target ORx and Oreo can act as potential repellents by disrupting odor-sensing activity in insects. In this context, linalool and eucalyptol were identified as the principal compounds in the essential oil extracted from $O$. basilicum, which have been shown to activate odorant receptor neurons in mosquito antennal sensilla, thereby confusing insects. Thus, it can be assumed that this mechanism would account for the observed repellency of the essential oil of this plant. Accordingly, a repellent natural, less toxic, based on odor sensing could conceivably represent a new strategy for developing repellents or compounds with novel modes of action against arthropods (Lee, 2018). In addition, phenolic compounds are part of the secondary metabolism of several plants, being well known for acting as a repellent of adult insects, preventing oviposition, impairing feeding and growth, as well as promoting morphogenetic and hormonal system alterations, sexual behavior changes, and adult sterilization (Dietrich et al., 2011; Cozzer et al., 2021). Thus, it is possible that the repellent effect of A. glazioveana extracts in this study involves the activities of flavonoids on adult A. aegypti mosquitoes. 
Figure 2. Effect of topical treatments on the number of stinging attempts by Aedes aegypty females $(\mathrm{n}=3)$. NC (negative control): forearms without treatment; Veh (vehicles for body creams or alcoholic spray): DEET (positive control). (A) Effects of body cream based on hydroalcoholic extract (HEA) and dichloromethane (DEA) of Ateleia glazioveana (5\%). (B) Effect of alcoholic spray based on Ocimum basilicum 5\% essential oil (OEO). **p $<0.01$ and ***p $<0.001$ compared to Veh.
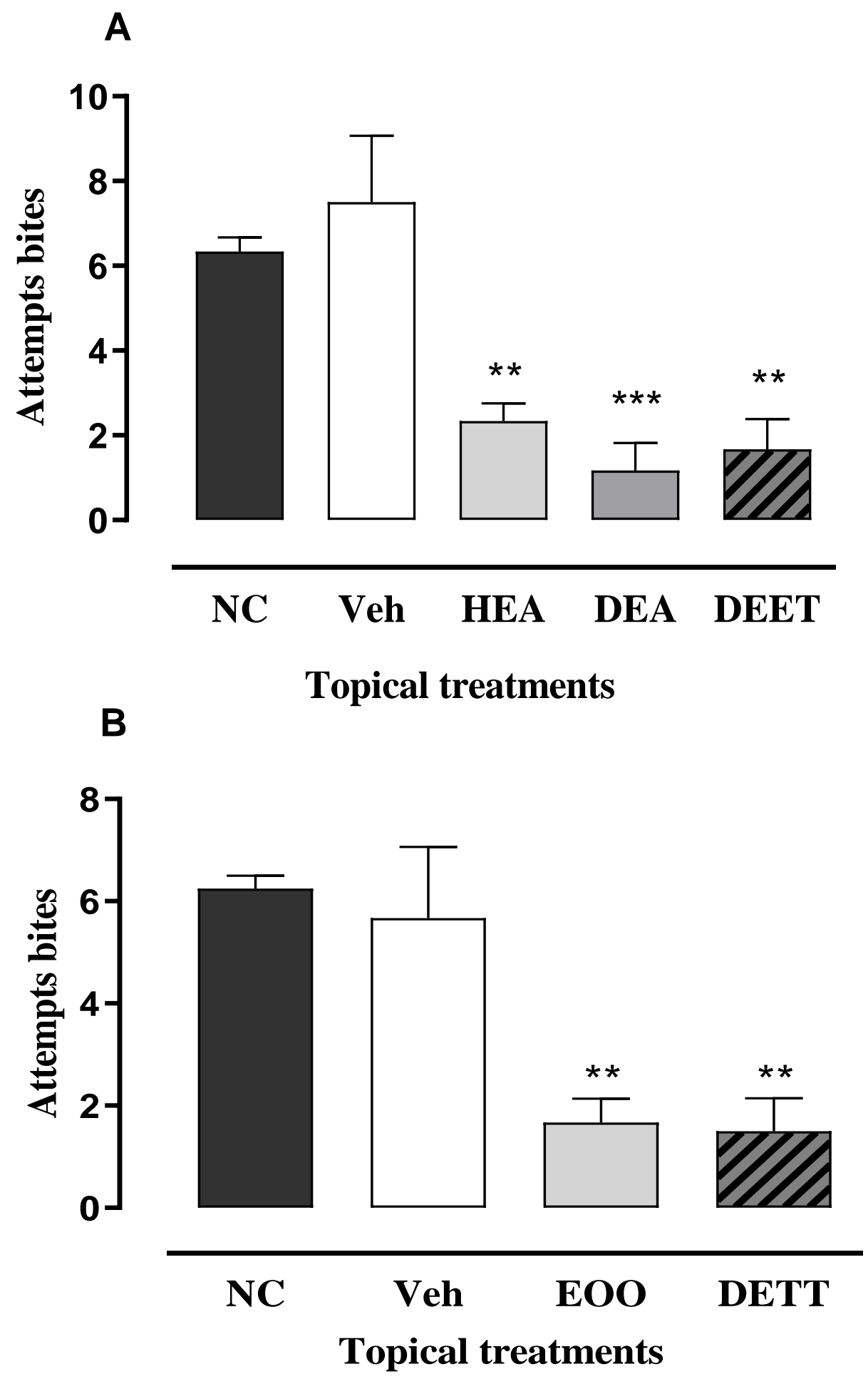

Source: Authors. 


\section{Conclusion}

The dichloromethane extract of Ateleia glazioveana exhibit effective larvicidal activity toward Aedes aegypti. Moreover, the dichloromethane and hydroalcoholic extracts of this plant applied in the form of body creams, and a hydroalcoholic spray based on the essential oil derived from Ocimum basilicum, demonstrate repellant activity toward adult mosquitoes of $A$. aegypti. Future studies will be able to prospect molecules isolated from these plants and advance in obtaining safer and more effective larvicides and repellants, without contaminating the environment.

\section{Acknowledgments}

This work was supported Coordination for the Improvement of Higher Education Personnel - CAPES and the Unochapecó [modality Art. 170 and 171 - FUMDES].

\section{References}

Adams, R. P. (2007). Identification of essential oil components by gas chromatography/mass spectrometry. Allured Publishing.

Agarwal, A., Parida, M., \& Dash, P. K. (2017). Impact of transmission cycles and vector competence on global expansion and emergence of arboviruses. Reviews in Medical Virology, 27 (5), 1941.

Atanasov, A. G., Waltenberger, B., Pferschy-Wenzig, E.-M., Linder, T., Wawrosch, C., Uhrin, P., Temml, V., Wang, L., Schwaiger, S., Heiss, E. H., Rollinger, J. M., Schuster, D., Breuss, J. M., Bochkov, V., Mihovilovic, M. D., Kopp, B., Bauer, R., Dirsch, V. M. \& Stuppner, H. (2015). Discovery and resupply of pharmacologically active plant-derived natural products: A review. Biotechnology Advances, 33 (8), $1582-1614$.

Brasil. (2019). Farmacopeia Brasileira. Brasília.

Carneiro, V. C. S., Braz De Lucena, L., Figueiró, R. \& Victório, C. P. (2021). Larvicidal activity of plants from Myrtaceae against Aedes aegypti L. and Simulium pertinax Kollar (Diptera). Revista da Sociedade Brasileira de Medicina Tropical (Online), 54, (e00922020), 1-8.

Coelho, J. S., Santos, N. D. L., Napoleão, T. H., Gomes, F. S., Ferreira, R. S., Zingali, R, B., Coelho, L. C. B. B., Leite, S. P., Navarro, D. M. A. F. \& Paiva, P. M. G. (2009). Effect of Moringa oleifera lectin on development of Aedes aegypti larvae. Chemosphere, 77, $934-938$.

Copping, L. G. \& Duke, S. O. (2007). Natural products that have been used commercially as crop protection agents. Pest Management Science, 63 (6), 524554.

Corbel, V., Achee, N. L., Chandre, F., Coulibaly, M. B., Dusfour, I., Fonseca, D. M, Grieco, J., Juntarajumnong, W., Lenhart, A., Martins, A. J., Moyes, C., Ching., L. N. G., Pinto, J., Raghavendra, K., Vatandoost, H., Vontas, J., Weetman, D., Fouque, F., Velayudhan, R. \& David, J.P. (2016). Tracking insecticide resistance in mosquito vectors of arboviruses: the worldwide insecticide resistance network (WIN). PLoS Neglected Tropical Diseases, 10 (12), 4.

Cozzer, G. D., Rezende, R. S., Lutinski, J. A., Roman-Junior, W. A., Busato, M. A. \& Simões, D. A. (2021). How long is long enough? Decreasing effects in Aedes aegypti larval mortality by plant extracts over time. Revista Brasileira de Ciências Ambientais, 56 (2), 338-345.

Deshpande, R. S. \& Tipnis, H. P. (1997). Insecticidal activity of Ocimum basilicum L. Pesticides, 11, 1-12.

Diaz, J. H. (2016). Chemical and plant-based insect repellents: efficacy, safety, and toxicity. Wilderness \& Environmental Medicine. 27 (1), $153-163$.

Dietrich, F., Strohschoen, A. A. G., Schultz, G., Sebben, A. D. \& Rempel, C. (2011). Utilização de inseticidas botânicos na agricultura orgânica de arroio do meio / RS. Revista Brasileira de Agrociências, 17, 251-255.

Franco, I. J. \& Fontana, V. L. (1997). Ervas \& plantas: a medicina dos simples. Imprimax.

Garcez, W. S., Garcez, F. R., Silva, L. M. G. E. \& Sarmento, U. C. (2013). Substâncias de origem vegetal com atividade larvicida contra Aedes aegypti. Revista Virtual de Química, 5 (3), 363-393.

Gava A. \& Barros, C. S. L. (2001). Field observations of Ateleia glazioviana poisoning in cattle in Southern Brazil. Veterinary and Human Toxicology, 43 (1), 37-41.

Guarda, C., Lutinski, J. A., Roman-Junior, W. A. \& Busato, M. A. (2016). Atividade larvicida de produtos naturais e avaliação da susceptibilidade ao inseticida temefós no controle do Aedes aegypti (DIPTERA: CULICIDAE). Interciencia, 41 (4), 243-247.

Idris, M. M., Mudi, S. Y. \& Datti, Y. (2014). Phytochemical screening and mosquito repellent activity of the Stem Bark extracts of Euphorbia balsamifera (Ait). ChemSearch Journal, 5 (2), 46-51.

Isman, M. B. (2006). Botanical insecticides, deterrents, and repellents in modern agriculture and an increasingly regulated world. Annual Review of Entomology, 51, 45-66. 
Knowlton, J. \& Pearce, S. (1993). Handbook of cosmetic science and technology. Elseveir Science Publications.

Lee, C. C. \& Houghton, P. (2005). Cytotoxicity of plants from Malaysia and Thailand used traditionally to treat cancer. Journal of Ethnopharmacology, 100 (3), 237-243.

Lee, M. Y. (2018). Essential oils as repellents against arthropods. BioMed Research International, 2018, 1-9.

Lima-Camara, T. N. (2016). Arboviroses emergentes e novos desafios para a saúde pública no Brasil. Revista de Saúde Pública, 50 (36), 1-7.

Long, R. A. (1995). Livro das árvores: árvores e arvoretas do Sul. L\&PM.

Lorenzi, H. \& Matos, F. J. A. (2002). Plantas medicinais no Brasil: nativas e exóticas, Plantarum. Nova Odessa.

Migliorini, P., Lutinski, J. A. \& Garcia, F. R. M. (2010). Eficiência de extratos vegetais no controle de Diabrotica speciosa (Germar, 1824) (Coleoptera: Chrysomelidae), em laboratório. Biotemas, 23 (1), 83-89.

Moore, S. J. \& Debboun, M. (2007). Insect Repellents: principles, methods, and uses. CRC Press, Boca Raton.

Newman, D. J. \& Cragg, G. M., (2016). Natural products as sources of new drugs over the period 1981-2014. Journal of Natural Products, 79 (3), 629-661.

Ortega, G. G. \& Schenkel, E. P. (1986) Isoflavonas de Ateleia glazioviana Baill (Leguminosae). Cadernos de Farmacologia, 2 (2), $133-161$.

Ortega, G. G. \& Schenkel, E. P. (1987). Ichthyotoxic activities of Ateleia glazioviana Baill and Thinouia coriaceae Brit. Journal of Ethnopharmacology, 20 (2), 81-84.

Paula, J. P., Farago, P. V., Checchia, L. E. M., Hirose, K. M. \& Ribas, J. L. C. (2004). Atividade repelente do óleo essencial de Ocimum selloi Benth. (variedade eugenol) contra o Anopheles braziliensis Chagas. Acta Farmaceutica Bonaerense, 23 (3), 376-378.

Pandey, A. K., Singh, P. \& Tripathi, N. N. (2014). Chemistry and bioactivities of essential oils of some Ocimum species: an overview. Asian Pacific Journal of Tropical Biomedicine, 4 (9), 682-694.

Paumgartten, F. J. R. \& Delgado, F. I. (2016). Repelentes de mosquitos, eficácia para prevenção de doenças e segurança do uso na gravidez. Vigilância Sanitária em Debate, 4 (2), 97-104.

Pavela, R. (2016). History, presence and perspective of using plant extracts as commercial botanical insecticides and farm products for protection against Insects - A review. Plant Protection Science, 52 (4), 229-241.

Pereira, A. S., Shitsuka, D. M., Pereira, J. F., Shitsuka, R. (2018). Scientific research methodology. [free e-book]. Santa Maria/RS. Ed. UAB/NTE/UFSM

Poopathi, S. \& Abidha, S. (2010). Mosquitocidal bacterial toxins (Bacillus sphaericus and B. thuringiensis serovar israelensis): Mode of action, cytopathological effects and mechanism of resistance. Journal of Physiology and Pathophysiology, 1 (3), $22-38$.

Rosa, J. P. P. (2016). Resistência de Aedes aegypti ao inseticida Temefós. Revista da Universidade do Vale do Rio Verde, 14 (1), $607-610$.

Scarsolini-Comin, F. (2021). Projeto de pesquisa em ciências da Saúde: guia prático para estudantes. 1. Ed. Petrópolis, RJ: Ed. Vozes.

Sharma, R. N., Bhosale, A. S., Joshi, V. N., Hebbalkar, D. S., Tungikar, V. B., Gupta, A. S. \& Patwardhan, S. A. (1981). Lavandula gibsonii: A plant with insectistatic potential. Phytoparasitica, 9 (2), 101-109.

Tyagi, A. K. \& Malik, A. (2012). Bactericidal action of lemon grass oil vapors and negative air ions. Innovative Food Science \& Emerging Technologies, 13, $169-177$.

Usta, J., Kreydiyyeh, S., Bakajian, K. \& Nakkash-Chmaisse, H. (2002). In vitro effect of eugenol and cinnamaldehyde on membrane potential and respiratory complexes in isolated rat liver mitochondria. Food and Chemical Toxicology, 40, 935-940.

Vasconcelos, J. N., Santiago, G. M. P., Lima, J. Q., Mafezoli, J., Lemos, T. L. G. D., Da Silva, F. R. L., Lima, M. A. S., Pimenta, A. T. A., Braz-Filho, R., Arriaga, A. M. C. \& Cesarin-Sobrinho, D. (2012). Rotenoids from tephrosia toxicaria with larvicidal activity against Aedes aegypti, the main vector of dengue fever. Quimica Nova, 35 (6), 1097-1100.

Woisky, R. G. \& Salatino, A. (1998). Analysis of propolis: some parameters and procedures for chemical quality control. Journal of Apicultural Research, 37 (2), 99-105.

World Health Organization. (2006). Guidelines for the Treatment of Malaria/WHO Library Cataloguing-in-Publication Data Switzerland.

Xavier, I., Valle, V., Lunkes, D., Nedel, A. S., Anarbor, V., Campos, M. M. A., Botton, S. A., Delbon, M. C. C. \& Sangion, L. A. (2013). Fatores epidemiológicos da dengue na região central do estado do Rio Grande do Sul, Brasil, 2007 - 2010. Ciência Rural, 43 (1), 87-91.

Zara, A. L. S. A., Santos, S. M., Fernandes-Oliveira, E. S., Carvalho, R. G. \& Coelho, G. E. (2016). Estratégias de controle do Aedes aegypti: uma revisão. Epidemiologia e Serviços de Saúde, 25 (2), 391-404. 